\title{
Need Analysis of Science E-book Based on Tri Pusat Pendidikan (Three Center of Education) Approach for Junior High School Students
}

\author{
Wahyu Anggraini Pramusinta ${ }^{1, *}$ I Gusti Putu Suryadarma ${ }^{2}$ Ikfi Nuril Khoiriza ${ }^{1,}$ \\ Devi Puspitasari ${ }^{1}$ \\ ${ }^{I}$ Master of Natural Science Education, Faculty of Mathematics and Natural Sciences, Universitas Negeri \\ Yogyakarta, Indonesia \\ ${ }^{2}$ Departement of Biology Education, Faculty of Mathematics and Natural Sciences, Universitas Negeri \\ Yogyakarta, Indonesia \\ Corresponding author. Email: wahyuanggraini.2019@student.uny.ac.id
}

\begin{abstract}
Learning media in the form of e-books have not been widely used, even though e-books have many benefits in supporting education. The aim of this study is to determine the needs for teaching materials in the form of a science e-book with Tri Pusat Pendidikan approach for junior high school students. This research used a descriptive method. The instrument of this research was in the form of questionnaire which was addressed to 20 science teachers teaching in junior high schools in the Sleman district. The instrument consisted of 5 aspects with 18 indicators. Based of the opinion of the science teacher, the results of the analysis for each aspect were obtained an average for aspects of student teaching materials of $88.75 \%$, aspects of learning media by $80.25 \%$, aspects of Tri Pusat Pendidikan in learning amounted to 79.69\%, and aspects of the needs of science e-book based on Tri Pusat Pendidikan approach of $86.75 \%$, and aspects of material needs "Pressure" with Tri Pusat Pendidikan approach of $88,75 \%$.
\end{abstract}

Keywords: E-book, Tri pusat pendidikan

\section{INTRODUCTION}

The development of technology in the $21^{\text {st }}$ century is so fast. Digitalization is a big challenge for the media industry. Many products are obtained through the media. One of them is in the world of education namely electronic books. Although the spread of e-book teaching materials is increasing in several countries, the majority of readers still refuse to leave paper books [1]. Students, parents and teachers have not made use of the features provided in the e-book. Most e-books that are presented are still the same as text books, there is no addition of animation, video or audio-visual in them [2]. That is one of the reasons readers prefer textbooks to e-book.

E-books will become more desirable when presented with supporting features. With a lot of supporting features in e-book, e-books have several advantages including giving interesting features which may not be found in the text book, having thesaurus, compatible (can be accessed or used at any time) and environmentally friendly [3]. Besides that, the advantages of using e-books can also make it easier to search for words or subjects by simply typing in keywords. There is an e-book update service which is portability, means one device can carry thousands of e-books, making it easier to adjust the font and font size according to users' preference, and it also saves space [4].

Most e-books are accessed via a computer or laptop in pdf or HTML format, so that it increases the convenience of e-book users [5]. According to several studies, the format of electronic books gives e-book advantages compared to printed books. Ebooks can be stored in portable devices such as laptops, computers or smartphones [5]. Besides these advantages, e-books are one of the most effective teaching materials in supporting online learning. 
Based on the results of research conducted by Gorghiu, e-books are proven as the right solution to support distance learning in the digital era and the process of e-learning through e-books is getting important [6].

Given the importance of distance learning, teachers must be able to deliver science materials, so that it is easily understood by students. E-books become one of the teaching material solutions that make it easier for students to understand the material. The use of e-books is easier, tends to be used frequently in learning, give an easier accessibility, provides an easier search for word or materials, and has important features in them [7]. However, the teaching materials presented in the e-book have not been much related to the environment around students. The problems presented were far from what students experienced. Therefore, students find it difficult to understand each subject matter, especially in science learning which requires skills in explaining abstract material so that it is easy for students to make an analogy. Therefore, we need an approach that is able to solve these problems. Delivering material with a student learning environment approach is a solution in making it easier for students to understand each subject matter.

The role of family, school, community is needed in increasing students' conceptual understanding. A planned education helps the potential and abilities of students which are not only the responsibility of the government but also parents, schools and communities [8]. The educational environment that plays an important role in children's education by $\mathrm{Ki}$ Hadjar Dewantara is called Tri Pusat Pendidikan. The Tri Pusat Pendidikan have the responsibility for the implementation of education for children. It includes education in the family, education in schools and education in the community [9].

Education in the family is not just words but in the form of actions and is carried out by parents in the family environment [10]. In the implementation of science learning, students can gain knowledge based on events that are often encountered at home, both carried out by students or parents in everyday life. Education in a community environment has a major influence on activities related to educational issues. When students become a part of the community, that's where the educational process begins [11]. In the implementation of science learning, students can find interactions between living beings in their environment, whether animals, plants or humans. One example of the application of science that students can get in the community is studying plant behavior, animal behavior, factors that cause natural disasters, pollution levels in their living environment and many more. Furthermore, education in the school environment has an important role in developing knowledge, attitudes and behavior to become mature, insightful, ethical and responsible individuals [12]. In the implementation of science learning, students can strengthen their knowledge based on what is observed in their environment and deepen the material of each subject so that there will not be any misconceptions.

Because of its importance, Tri Pusat Pendidikan approach should be applied in learning. In fact, there are still many teaching materials that have not used this approach in delivering science material. Most of the teaching materials provided go directly to definitions and theories without students fully understand where the definitions, theories, laws and formulas come from. Teaching materials for the ebook based on Tri Pusat Pendidikan approach is an innovation in terms of science teaching materials. Therefore, this research article is aimed to determine the teacher's need for teaching materials for the science e-book based on Tri Pusat Pendidikan approach for junior high school students. The analysis of the needs for teaching materials for the science e-book based on Tri Pusat Pendidikan approach is related to five aspects, namely aspects of student teaching materials, aspects of learning media, aspects of the Tri Pusat Pendidikan in learning, aspects of the need for science e-books based on Tri Pusat Pendidikan approach and aspects of material needs "Pressure" with the Tri Pusat Pendidikan approach.

\section{RESEARCH METHOD}

This study used descriptive method. The instrument of this study was in the form of questionnaire of the needs for the development of science e-book based on Tri Pusat Pendidikan approach and the material needs for "Pressure" with Tri Pusat Pendidikan approach. It was addressed to 20 science teachers teaching in Yogyakarta. The technique of selecting teachers as subjects in this study used purposive sampling with the consideration that the selected teachers are science teachers who teach in junior high schools in the Sleman district. The questionnaire used Likert scale with 4 answers.

The object of this study was the need of teachers and students to teaching and learning materials in the form of an e-book based on Tri Pusat Pendidikan approach and also the importance of delivering material "Pressure" based on Tri Pusat Pendidikan 
approach for junior high school students. The data analysis technique was by collecting data that had been obtained through an online questionnaire and then analyzed using a qualitative analysis method with a narrative study of the study results. The analysis included the parts listed on each aspect of the indicator, then reformulated to draw conclusions about the needs of teachers related to the science ebook teaching materials based on Tri Pusat Pendidikan approach in learning.

\section{RESULT AND DISCUSSION}

Based on the questionnaire given to junior high school science teachers in Sleman district via google form. Then an analysis of each aspect was carried out. It is used to find out how much science ebook Tri Pusat Pendiidkan is needed in junior high schools., the analysis results for each measured aspect are presented in the histogram in Figures 1,2, 3, 4 and 5.

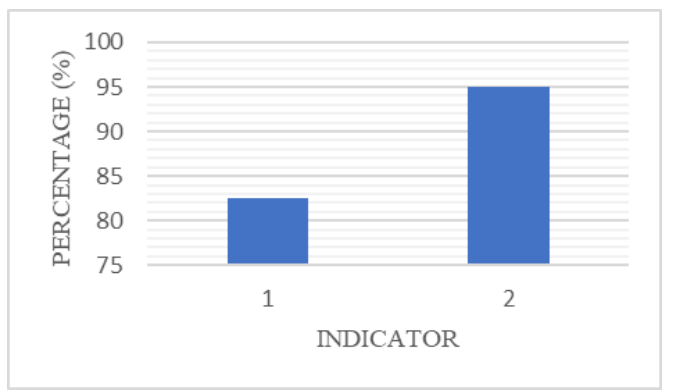

Figure 1 Results of the analysis of student teaching material aspects

The Figure 1 above is the result of an analysis of aspects student teaching materials in schools. This aspect consisted of two indicators, namely the use of textbooks as teaching materials for students and the use of audio-visual aided teaching materials. The average yield obtained in this aspect was $88.75 \%$. The results showed that, the teaching materials used by students every day are in the form of text books, while the use of learning media is still less. Even though the use of learning media in the classroom is very attractive to students.

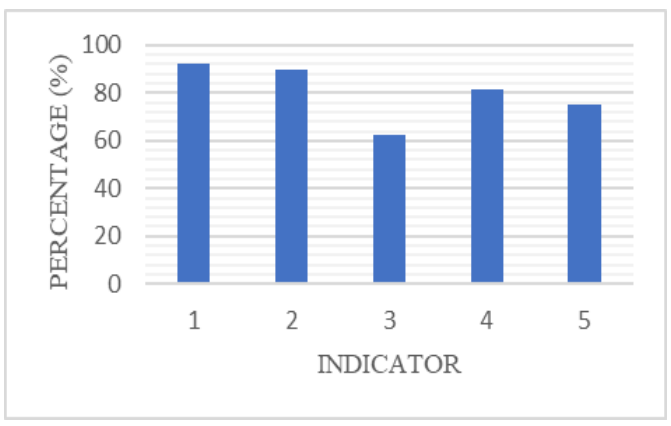

Figure 2 Results of aspect analysis learning media
The Figure 2 above is the result of an analysis of aspects of learning media. This aspect consisted of 5 indicators. The five indicators consecutively were the delivery of material in using learning media, the use of learning media compared to textbooks, the difficulty of using learning media, the use of interactive learning media, and the making of audiovisual learning media. The average result obtained in this aspect was $80.25 \%$. these results indicate that the use of learning media greatly supports the learning process of students in the classroom.

The figure 3 below is the result of an analysis of the Tri Pusat Pendidikan aspects in learning. This aspect consisted of 4 indicators. The four indicators were the understanding of the Tri Pusat Pendidikan, the use of the Tri Pusat Pendidikan approach in learning, solving problems in the student environment, and relating the material to the student's environmental conditions. The results obtained from this aspect were to $79.69 \%$. From these results, it shows that Tri Pusat Pendidikan approach in learning has an important influence in the achievement of learning objectives, but the learning carried out has not fully used this approach.

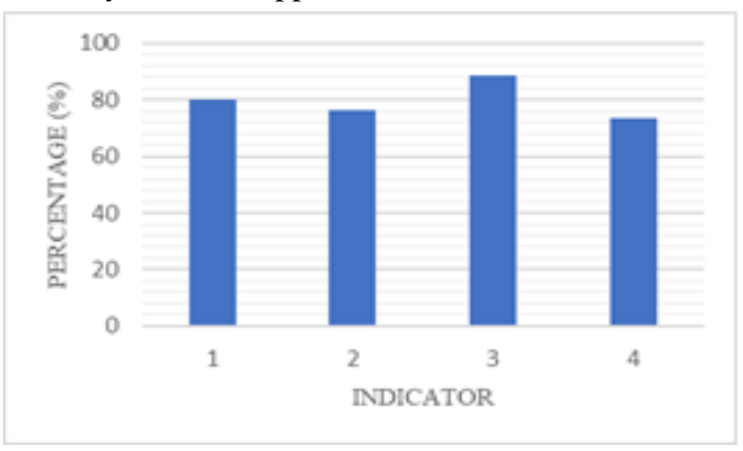

Figure 3 Results of the tri pusat pendidikan aspect analysis in learning

The Figure 4 below is the result of an analysis of aspects of the development of a science e-book based on Tri Pusat Pendidikan approach. This aspect consisted of 4 indicators. The four indicators were $90 \%$ of the use of science e-books made it easier for students to understand the subject matter, $78.75 \%$ of the e-books used had not made use of the features so they are no different from textbooks, $78.75 \%$ of use Science e-book based on Tri Pusat Pendidikan approach had not been widely used in learning, and $100 \%$ science e-books were needed to support classroom learning. The average result obtained in this aspect was $86.75 \%$. 


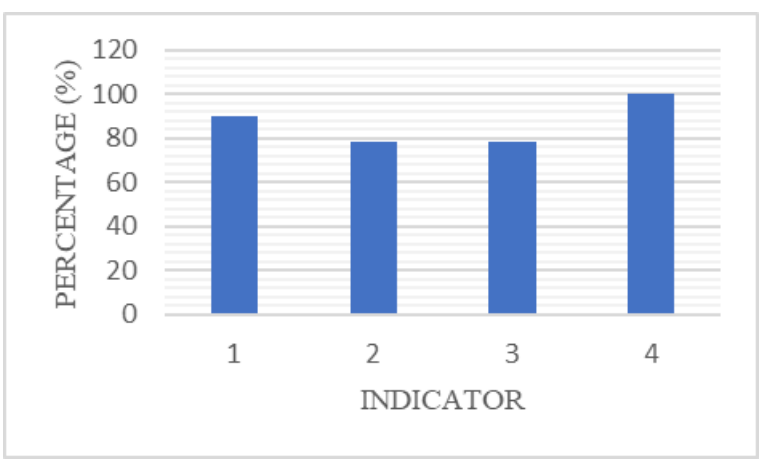

Figure 4 Results of aspect needs analysis science ebook based on tri pusat pendidikan approach

The Figure 5 below is the result of an analysis of the aspect of material needs "Pressure" based on Tri Pusat Pendidikan approach. This aspect consists of 3 indicators. The three indicators consecutively, $73.75 \%$ of the delivery of "Pressure" material to students had not fully used the Tri Pusat Pendidikan approach, $96.25 \%$ of the delivery of "Pressure" material based on Tri Pusat Pendidikan approach made it easier for students to understand the material, and $96.25 \%$ makes it easier for students to build concepts related to "Pressure" material. The average result obtained in the aspect of material analysis is $88.75 \%$.

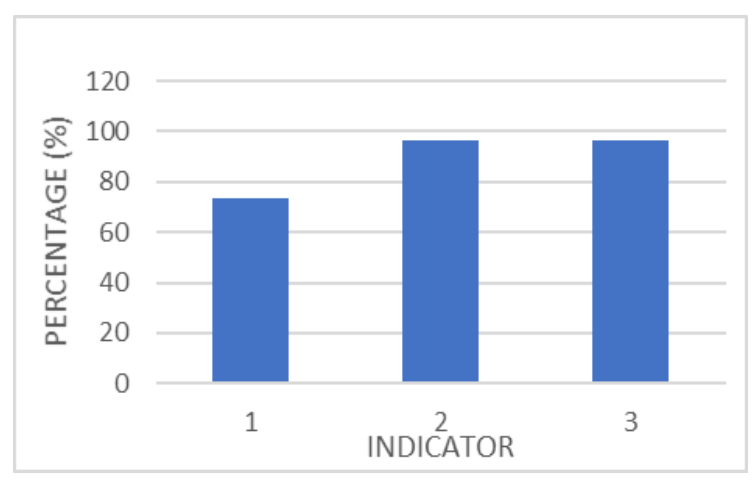

Figure 5 Results of the aspect analysis of "pressure" material needs based on tri pusat pendidikan approach

Based on the analysis results of the five aspects above, it can be seen that in the first aspect regarding the results of the analysis of teaching materials, $82.5 \%$ students still used textbooks, while $95 \%$ of the use of audio visuals as teaching materials was more supportive for students. The use of media can make it easier for students to obtain more real information so that they can deepen their understanding. Students also found it easier to understand the materials because it helped students to learn faster than given explanation by others. In addition, the presence of videos, pictures, and animations can increase students' motivation and enthusiasm for learning [13]. From this, we know that the media has an important role in the learning process, especially to deepen the level of students' understanding.

The results of the analysis of the aspects of learning media showed that $92.5 \%$ of the delivery of science material using learning media makes it easier for teachers and students in learning science. This was supported by $90 \%$ of students who preferred learning assisted by audio-visual media than textbooks. However, teachers still have difficulty in delivering material using learning media, this was proven by $62.5 \%$ of teachers who cannot use instructional media in delivering material. Even though, we know that using learning media can help students in learning. The difficulty of teachers in delivering learning media was due to the lack of socialization of training related to interactive media development. Learning media has a significant influence in the world of education, so that teachers must be able to make their own learning media as an effective tool in education [14]. With more teachers who make their own learning media, the multimedia collaboration system will occur which will provide greater benefits to the world of education. If each teacher is connected in a wider area in a collaborative system, then they can exchange multimedia content, so that it will broaden the perspective of improvement not only in the educational process but also improving the experience of teachers in teaching [15].

In the Tri Pusat Pendidikan aspect of learning, it showed that $88.75 \%$ of the delivery of material by relating events in the environment made it easier for students to understand the material. Considering the importance of the Tri Pusat Pendidikan approach, there are still many teachers who have not applied this approach in learning process. This was proven by the lowest percentage in this aspect which reached $73.75 \%$. This result is strengthened by the percentage of the second indicator which reached $76.25 \%$ which indicates that teachers rarely used the Tri Pusat Pendidikan approach. In this aspect, the second indicator is the second lowest indicator after the fourth indicator. In fact, the data showed that $80 \%$ of teachers understood the meaning of Tri Pusat Pendidikan. From these data, we knew that teachers undersood the importance of Tri Pusat Pendidikan, but there were still many teachers who had not implemented them in the learning process. The importance of the educational environment in helping students interact with the surrounding environment makes it easier to achieve optimal educational goals [16]. From this we knew that using the Tri Pusat Pendidikan approach in learning will help achieving optimal goals. 
In the aspect of the needs for a science e-book based on Tri Pusat Pendidikan approach, 90\% of teachers agreed that the teaching material in the form of an e-book with features in it can make it easier for students to understand science material. Meanwhile, $78.75 \%$ of the e-books developed had not made use its features such as audio visuals in the delivery of material and the science e-books used had not used the Tri Pusat Pendidikan approach. Therefore, 100\% teachers stated that the science e-book teaching materials with Tri Pusat Pendidikan approach were needed to support science learning in the classroom. Many features in e-book can be used to present audio visuals with events in the student environment. So that learning becomes more real and easy to be understood by students.

In the aspect of material needs, "Pressure" based on Tri Pusat Pendidikan approach shows that the delivery of science material, especially "Pressure" is highly recommended to use the Tri Pusat Pendidikan approach, this is indicated by a percentage of $88.75 \%$. The suitability of the material with the approach used will have a positive impact on the teaching and learning process in the classroom. Students will easily accept every material they learn, and can implement it in everyday life. In order for the implementation of learning to run smoothly, the use of teaching materials in the form of e-books is one of the solutions in delivering the material. So that the "Pressure" material can be conveyed easily, pleasantly, and is able to attract students attention.

\section{CONCLUSION}

Based on the results of data analysis from the five aspects above, it can be concluded that teaching materials are needed in the form of a science e-book based on Tri Pusat Pendidikan approach for junior high school students. This is important considering that the teaching materials which is usually used are textbooks. Delivering material assisted with learning media makes it easier for students to deepen their understanding of the material being studied. This science e-book based on Tri Pusat Pendidikan approach can be used in the student learning process both at school and at home.

\section{REFERENCES}

[1] J. Gerlach, P. Buxmann, Analyzing Electronic book acceptance: a compatibility perspective, in: 46th Hawaii International Conference on System Sciences, vol. 2013, Hawai, 2013, no. 1, pp. 2813-2822, DOI:

\section{https://doi.org/10.1109/HICSS.2013.94}

[2] C. Liu, K.H. Tseng, L.Y. Wu, A Participatory Learning Framework for Enhancing Children's Reading Experience with Electronic Book Readers, Research \& Practice in Technology Enhanced Learning 8(1) (2013) 129-151.

[3] S. Jindal, A. Pant, Availability of E-Books in Science: Case Study of University of Delhi, The Electronic Library 31(3) (2013) 313-328. DOI: https://doi.org/10.1108/EL-12-2010-0159

[4] F.M. Cheek, L.J. Hartel, The Electronic Book Beginnings to The Present, Building and Managing E-Book Collections: A How-to-do-it Manual for Librarians, 2012.

[5] B. Ebiwolate Posigha, The Use and Future of Electronic Books in Academic Institutions in Nigeria, The Electronic Library 30(6) (2012) 796-808.

[6] L.M. Gorghiu, G. Gorghiu, M. Bîzoi, A.M. Suduc, The electronic book - a modern instrument used in teachers' training process, in: Procedia Computer Sciences, vol. 3, Elsevier, Amsterdam, 2011, pp. 563-567, 2011. DOI: https://doi.org/10.1016/j.procs.2010.12.093

[7] M. Nasser Al-Suqri, Perceived Usefulness, Perceived Ease-of-Use and Faculty Acceptance of Electronic Book, Library Review 63(4) (2014) 276-294. DOI: https://doi.org/10.1108/LR-05-2013-0062

[8] Musbaing, Educational Policy, Internationa journal of Asian Education 1(2) (2020) 53-60. DOI: https://doi.org/10.46966/ijae.v1i2.35

[9] M.I. Kurniawan, Tri Pusat Pendidikan sebagai Sarana Pendidikan Karakter Anak Sekolah Dasar, Pedagogik Jurnal Pendidikan 4(1) (2015) 41-51.

DOI: https://doi.org/10.21070/pedagogia.v4i1.71

[10] T. Santika, Peran Keluarga, Guru dan Masyarakat dalam Pembentukan Karakter Anak Usia Dini, Jurnal Pendidikan UNSIKA 6(1) (2018) 77-78.

[11] R.F. Saleh, Reinterpretasi Tri Pusat pendidikan: Sebuah Telaah Kritis Filosifis-Pedagogis, Jurnal Elementary Education 3(2) (2020) 58-63.

[12] L.N.K. Dewi, Tri Pusat Pendidikan dan Literasi sebagai Elemen Strategis Penguatan Karakter dan Pencerdasan Bangsa, MAHA WIDYA BHUWANA 1(2) (2018) 2621-1025.

[13] F.T. Leow, M. Neo, Interactive Multimedia Learning: Innovating Classroom Education in a Malaysian University, Turkish Online Journal 
Technology 13(2) (2014) 99-110.

[14] M.E.A. Babiker, for Effective Use of Multimedia in Education, Teachers Must Develop Their Own Educational Multimedia Applications, Turkish Online Journal Educational Technology 14(4) (2015) 62-68.

[15] Z. Kotevsk, I. Tasevska, Evaluating the Potentials of Educational Systems to Advance Implementing Multimedia Technologies, International Journal of Modern Education and Computer Science 9(1) (2017) 26-35. DOI: https://doi.org/10.5815/ijmecs.2017.01.03

[16] N. Hidayati, Konsep Integrasi Tri Pusat Pendidikan Terhadap Kemajuan Masyarakat, Edukasia Jurnal Penelitian Pendidikan Islam 11(1) (2016) 203-224. 